\title{
Surface Persistence of SARS-CoV-1 MERS and SARS-CoV-2 Viruses and Effective Biocidal Agents: An
} Insight

\author{
Agami Mehta ${ }^{1}$, Vandana Laxman ${ }^{2}$
}

\begin{abstract}
The novel coronavirus disease is the ongoing pandemic that is caused by severe acute respiratory syndrome coronavirus or SARS-CoV-2. The disease continues to create havoc globally and has created fears in the mind of individuals regarding its spread and transmission. Transmission among humans occur through close contact with an infected individual who may produce respiratory droplets while coughing and sneezing which can remain in air and/or settle on inanimate objects. Therefore, knowledge about the persistence of the virus on various surfaces helps in alleviating irrational fears and also aids in controlling the spread of infection. In this review, an effort was made to compile the data on the persistence of the human coronaviruses such as SARS-CoV-1, Middle East respiratory syndrome (MERS), and SARS-Cov-2 on various surfaces and the biocidal agents that are effective against them.

Keywords: Biocidal, Coronavirus, Disinfection, Persistence surface, Survival skin, Survival surface.

CODS Journal of Dentistry (2021): 10.5005/jp-journals-10063-0083
\end{abstract}

\section{INTRODUCTION}

On March 11, 2020, the World Health Organization (WHO) declared (SARS-CoV-2 as a pandemic that causes novel coronavirus disease2019 (COVID-19).

Infected individuals reported with common clinical symptoms involving fever, nonproductive cough, myalgia, shortness of breath, and normal or reduced leukocyte counts. 'In addition, severe cases of infection presented with pneumonia, SARS, kidney failure, and eventually leading to death.

Transmission among humans occurs via close contact with an infected individual that produces respiratory droplets while coughing or sneezing within a range of $6 \mathrm{ft} .^{2}$ Transmission of coronaviruses from contaminated dry surfaces has been postulated including self-inoculation of mucous membranes of the nose, eyes, or mouth. Therefore, it is important to have a detailed understanding of persistence of this virus on inanimate surfaces. ${ }^{3}$

Various types of biocidal agents such as hydrogen peroxide, alcohols, and sodium hypochlorite are used worldwide for disinfection, mainly in healthcare settings. ${ }^{3}$

Dental professionals are at high risk and can become potential carriers of the disease. These risks can be attributed to the unique nature of dental interventions, which include aerosol generation, handling of sharps, and proximity to the patient's oropharyngeal region. If adequate precautions are not taken, the dental office can potentially expose patients to cross-contamination. ${ }^{4}$

The emergence of the COVID-19 and its pandemic nature has exacerbated fears worldwide. With the high levels of fear, individuals may not think clearly and rationally when reacting to COVID-19. ${ }^{5}$ Currently, easy access to communication technologies and the spread of inaccurate or false information can increase harmful social reactions, such as fear, anger, and aggressive behavior. Thus accurate information and evidence-based data play a crucial role in managing the current situation.

\footnotetext{
1,2Department of Periodontics, College of Dental Sciences, Davangere, Karnataka, India
}

Corresponding Author: Vandana Laxman, Department of Periodontics, College of Dental Sciences, Davangere, Karnataka, India, Phone: +8192-231285, e-mail: vanrajs@gmail.com

How to cite this article: Mehta A, Vandana L. Surface Persistence of SARS-CoV-1 MERS and SARS-CoV-2 Viruses and Effective Biocidal Agents: An Insight. CODS J Dent 2021;13(1):18-23.

Source of support: Nil

Conflict of interest: None

A Medline search was conducted in August 2020. The following terms were used along with coronavirus, SARS, MERS, persistence, surface, persistence skin, persistence hands, survival skin, inanimate survival, and disinfection. Publications with human coronaviruses were included. Only one article was found on SARS-CoV-2 that evaluated the stability of the virus in aerosols and common inanimate surfaces.

Therefore, an attempt has been made in this article to compile information on the stability of SARS-CoV-2 and various other human coronaviruses on inanimate objects which are a part of the dental office as well as our routine life and also commonly used biocidal agents that are effective against coronaviruses for surface disinfection.

\section{Stability of Human Coronaviruses on Surfaces}

Various studies related to the stability of human coronaviruses including SARS-CoV-2 are presented in Table 1. The surfaces that were studied included copper, stainless steel, aluminum, metal, plastic, cardboard, teflon, polytetrafluoroethylene (PTFE), ceramic, glass, polyvinyl chloride (PVC), silicone rubber, wood, paper, and cloth. Cotton gauzes, latex surgical gloves, disposable gown, and cotton gowns were also evaluated. Table 2 lists out the surfaces

() The Author(s). 2021 Open Access This article is distributed under the terms of the Creative Commons Attribution 4.0 International License (https://creativecommons. org/licenses/by-nc/4.0/), which permits unrestricted use, distribution, and non-commercial reproduction in any medium, provided you give appropriate credit to the original author(s) and the source, provide a link to the Creative Commons license, and indicate if changes were made. The Creative Commons Public Domain Dedication waiver (http://creativecommons.org/publicdomain/zero/1.0/) applies to the data made available in this article, unless otherwise stated. 
Table 1: Studies done to evaluate persistence of the coronaviruses on inanimate and living surfaces

\begin{tabular}{|c|c|c|c|c|}
\hline Author and year & Virus and strain used & Methodology & Method for viral identification & Results and conclusion \\
\hline $\begin{array}{l}\text { Von Doremalen } \\
\text { et al. }{ }^{6}\end{array}$ & $\begin{array}{l}\text { SARS-CoV-2 } \\
\text { nCoV-WA1-2020 } \\
\text { SARS-CoV-1 } \\
\text { Tor2 (AY 274,119.3) }\end{array}$ & $\begin{array}{l}\text { Viruses were applied to copper, } \\
\text { cardboard, stainless steel, and } \\
\text { plastic maintained at } 21 \text { to } 23^{\circ} \mathrm{C} \\
\text { and } 40 \% \text { relative humidity over } \\
7 \text { days. } \\
\text { Aerosols were generated using a } \\
\text { three-jet collision nebulizer and } \\
\text { fed into a Goldberg drum to cre- } \\
\text { ate an aerosolized environment. } \\
\text { Samples were collected at } 0,30 \text {, } \\
60,120 \text {, and } 180 \text { minutes post- } \\
\text { aerosolization on a gelatin filter }\end{array}$ & $\begin{array}{l}\text { Viable virus in all surface and } \\
\text { aerosol samples was quanti- } \\
\text { fied by end-point titration on } \\
\text { Vero E6 cells. }\end{array}$ & $\begin{array}{l}\text { Aerosol and fomite transmission } \\
\text { of } S A R S-C o V-2 \text { is plausible, since } \\
\text { the virus can remain viable and } \\
\text { infectious in aerosols for } 3 \text { hours, } \\
\text { Copper for } 4 \text { hours, } \\
\text { Cardboard for } 24 \text { hours, } \\
\text { Stainless steel for } 72 \text { hours ( } 3 \\
\text { days) and plastic for } 72 \text { hours ( } 3 \\
\text { days) }\end{array}$ \\
\hline Warnes et al. ${ }^{7}$ & $\begin{array}{l}\text { Human coronavirus } \\
229 \mathrm{E}\end{array}$ & $\begin{array}{l}\text { Infected cell lysate prepara- } \\
\text { tions of HuCoV-229E were } \\
\text { spread over coupons of the test } \\
\text { surface and incubated at room } \\
\text { temperature. } \\
\text { Surface materials used were } \\
\text { polytetrafluoroethylene (teflon; } \\
\text { PTFE), polyvinyl chloride (PVC), } \\
\text { ceramic tiles, glass, silicone rub- } \\
\text { ber, and stainless steel }\end{array}$ & $\begin{array}{l}\text { Virus was removed and } \\
\text { assayed for infectivity at vari- } \\
\text { ous time point by a plaque } \\
\text { assay which was a modifica- } \\
\text { tion of the murine norovirus } \\
1(\text { MNV-1) assay }\end{array}$ & $\begin{array}{l}\text { Coronavirus persists in an infec- } \\
\text { tious state on common surface } \\
\text { materials such as polyfluoro- } \\
\text { tetraethylene (teflon; PTFE), } \\
\text { polyvinyl chloride (PVC), ceramic } \\
\text { tiles, glass, and stainless steel for } \\
\text { at least } 5 \text { and } 3 \text { days for silicon } \\
\text { rubber at } 21^{\circ} \mathrm{C} \text { and a relative } \\
\text { humidity of } 30-40 \%\end{array}$ \\
\hline $\begin{array}{l}\text { Von Doremalen } \\
\text { et al. }{ }^{8}\end{array}$ & $\begin{array}{l}\text { MERS-CoV (isolate } \\
\text { HCoV-EMC/2012) }\end{array}$ & $\begin{array}{l}\text { Stability of MERS was evaluated } \\
\text { under three different environ- } \\
\text { mental conditions on plastic } \\
\text { and stainless steel and also } \\
\text { aerosols }\end{array}$ & $\begin{array}{l}\text { Collected aerosols were } \\
\text { analyzed by quantitative } \\
\text { real-time polymerase chain } \\
\text { reaction (qRT-PCR) and by } \\
\text { virus titration }\end{array}$ & $\begin{array}{l}\text { MERS-CoV virus could still be } \\
\text { recovered after } 48 \text { hours at the } \\
20^{\circ} \mathrm{C}-40 \% \mathrm{RH} \text { condition, } 8 \text { hours } \\
\text { at } 30^{\circ} \mathrm{C}-80 \% \mathrm{RH} \text {, and } 24 \text { hours } \\
\text { at } 30^{\circ} \mathrm{C}-30 \% \mathrm{RH} \text {. MERS-CoV has } \\
\text { the ability to be transmitted via } \\
\text { aerosols as well }\end{array}$ \\
\hline Chan et al. ${ }^{12}$ & SARS-CoV HKU 39849 & $\begin{array}{l}\text { Virus was placed in individual } \\
\text { wells of a } 24 \text {-well plastic plate } \\
\text { (representing a nonporous } \\
\text { surface) and dried. } \\
\text { The dried virus was then } \\
\text { incubated at different tempera- } \\
\text { tures }\left(38,33,28^{\circ} \mathrm{C}\right) \text { at differ- } \\
\text { ent relative humidity }(>95 \% \text {, } \\
80-89 \%) \text { for } 3,7,11,13, \text { and } 24 \\
\text { hours and the residual viral in- } \\
\text { fectivity was titrated. Also virus } \\
\text { was incubated at room } \\
\text { temperature and relative hu- } \\
\text { midity of about } 40-50 \% \text { for up } \\
\text { to } 4 \text { weeks }\end{array}$ & $\begin{array}{l}\text { Appearance of cytopathic } \\
\text { effects was recorded daily. }\end{array}$ & $\begin{array}{l}\text { The dried virus on smooth } \\
\text { surfaces like plastic retained its } \\
\text { viability for over } 5 \text { days at tem- } \\
\text { peratures of } 22-25^{\circ} \mathrm{C} \text { and relative } \\
\text { humidity of } 40-50 \% \text {, }\end{array}$ \\
\hline Duan et al..$^{10}$ & SARS-CoV strain P9 & $\begin{array}{l}\text { Common household surfaces } \\
\text { such as metal, glass, wood } \\
\text { board, cloth, and plastic were } \\
\text { tested for stability of SARS- } \\
\text { coronavirus }\end{array}$ & $\begin{array}{l}\text { For analysis of stability of } \\
\text { coronavirus cytopathic ef- } \\
\text { fects was observed. }\end{array}$ & $\begin{array}{l}\text { Reduction of infectivity was seen } \\
72-96 \text { hours ( } 3-4 \text { days) after } \\
\text { exposure to various surfaces. }\end{array}$ \\
\hline Lai et al. ${ }^{11}$ & $\begin{array}{l}\text { SARS-CoV strain } \\
\text { GVU6109 }\end{array}$ & $\begin{array}{l}\text { To simulate the event of large } \\
\text { droplets that contain SARS- } \\
\text { CoV falling on paper and on } \\
\text { cotton and disposable gowns, } \\
\text { experiments were performed to } \\
\text { determine whether SARS-CoV } \\
\text { survived on these surfaces. }\end{array}$ & $\begin{array}{l}\text { Each specimen was placed } \\
\text { into a Vero E6 cell culture } \\
\text { tube and inoculated into } \\
\text { cell culture tubes. All of the } \\
\text { tubes were incubated at } \\
37^{\circ} \mathrm{C} \text { and were examined } \\
\text { after } 4 \text { days. }\end{array}$ & $\begin{array}{l}\text { Paper-24 hours } \\
\text { Cotton gown- } 24 \text { hours } \\
\text { Disposable gown- } 2 \text { days }\end{array}$ \\
\hline
\end{tabular}


Persistence of SARS-CoV-1 MERS and SARS-CoV-2 Viruses and Effective Biocidal Agents

\begin{tabular}{|c|c|c|c|}
\hline Author and year & Virus and strain used & Methodology & Method for viral identification \\
\hline Rabenau et al. $^{13}$ & $\begin{array}{l}\text { SARS-CoV isolate } \\
\text { FFM-1 }\end{array}$ & $\begin{array}{l}\text { They studied the stability of } \\
\text { SARS-CoV under different condi- } \\
\text { tions, both in suspension and } \\
\text { dried on polystyrene surface, in } \\
\text { comparison with other human- } \\
\text { pathogenic viruses, including } \\
\text { human coronavirus HCoV-229E }\end{array}$ & $\begin{array}{l}\text { Residual SARS-CoV } \\
\text { infectivity was detected by } \\
\text { recognition of cytopathic } \\
\text { effect (CPE) on Vero cells } \\
\text { and additionally by immu- } \\
\text { nostaining of infected cells } \\
\text { using convalescent serum } \\
\text { from a SARS patient }\end{array}$ \\
\hline Sizun et al. ${ }^{9}$ & $\begin{array}{l}\text { HCoV strains } 229 \mathrm{E} \text { and } \\
\text { OC43 }\end{array}$ & $\begin{array}{l}\text { Three different surfaces were } \\
\text { tested: aluminum, sterile cotton } \\
\text { gauze sponges, and sterile latex } \\
\text { surgical glove. Aliquots ( } 10 \\
\mu \mathrm{L} \text { ) of virus suspensions were } \\
\text { dropped on to each surface and } \\
\text { allowed to dry. }\end{array}$ & $\begin{array}{l}\text { Infectious virus titers were } \\
\text { calculated by the Karber } \\
\text { method, using four wells per } \\
\text { sample dilution }\end{array}$ \\
\hline
\end{tabular}

No data was found to describe the frequency of hands becoming contaminated with coronavirus, or the viral load on hands either, after patient contact or after touching contaminated surfaces.

MERS, Middle East Respiratory Syndrome; HCoV, human coronavirus; SARS, Severe Acute Respiratory Syndrome; RT, room temperature

and the studies done on them to assess the persistence of human coronaviruses.

\section{Biocidal Agents Effective Against Human Coronaviruses}

The various biocidal agents effective against coronaviruses and the studies related to them are listed in Table 3.

\section{Discussion}

A novel human coronavirus known as the SARS-CoV-2 emerged from Wuhan, China in December 2019. The disease was declared as a pandemic by the WHO and has spread across the whole world.

Severe acute respiratory syndrome coronavirus being an airborne virus, transmit via the same way as cold and flu virus do. The virus spreads by an infected person on coughing or sneezing leaving small droplets in the air or by stool. So the person who inhales such droplets or touches the infected surfaces may also get infected. ${ }^{19}$ Therefore, accurate information regarding the stability of the virus on inanimate objects will help us in preventing and controlling the pandemic.

At the time of data compilation (August 2020) only one article related to SARS-CoV-2 by van Doremalen et al. ${ }^{6}$ was available. They evaluated the stability of SARS-CoV-2 and SARS-CoV- 1 in aerosols and on various surfaces and estimated their decay rates. Almost all the other studies have presented the stability information of SARS-CoV-1, MERS, or other human coronaviruses.

The reason behind this compilation was to dig out the literature on stability of coronaviruses on various surfaces of routine life, as it has created havoc in the minds of human beings. The undue stress involved due to the spread of this pandemic has caused serious mental health issues leading to high levels of fear and anxiety in individuals. Therefore, this compilation of information aims to lessen that stress.

There are not many studies being conducted on this virus for the best known reason of transmission and spread of infection. However, the study by van Doremalen et al. is a good source of information on the stability of the virus on plastic, stainless steel, cardboard, and copper surfaces.

There is lack of information on specific time duration of stability of other two human coronaviruses (SARS-CoV-1 and MERS) as well.
The studies have used commercially available strains mostly, with very few of them using the actual virus due to the threat of infection transmission. However, these studies have made an attempt to provide us with a good source of information. Thanks to the authors!

Other studies included in this article serve as a source of information about the other human coronaviruses. These results cannot be extrapolated directly to SARS-CoV-2 due to the differences between the viruses. Studies have demonstrated that SARS-CoV-2 spike protein has higher affinity to the angiotensin-converting enzyme 2 (ACE2) receptor as compared with SARS-CoV-1 which is 10 to 20 times higher. ${ }^{20,21}$ Whereas MERS acts on a different receptor altogether, which is the dipeptidyl peptidase 4 (DPP4) receptor. But similarities have been detected between SARS-Cov-1 and SARS-CoV-2 in terms of genetic sequences. Sequence variation among their genome revealed no significant difference in open reading frames (ORFs) and nonstructural proteins (nsps). ${ }^{22}$ Regarding the transmissibility, the reproductive number or Ro of SARS-CoV-2 ranges between 2 and 2.5. Whereas that of SARS-Cov-1 was 1.7 to 1.9 and of MERS was $<1$. Also higher fatality rates were seen with MERS (34.4\%) and SARS-CoV-1 (9.5\%) as compared to SARS-CoV-2 (2.3\%). Also SARS-Cov-2 generally has a less severe clinical picture, and thus it can spread in the community more easily than MERS and SARS. ${ }^{23}$

\section{Persistence on Various Common Surfaces}

Persistence of coronaviruses on steel has been reported to be 72 hours ( 3 days), ${ }^{6} 48$ hours $\left(2\right.$ days ${ }^{8}$ and even 5 days. ${ }^{7}$ Persistence of coronaviruses on copper has been reported to be 4 to 8 hours, ${ }^{6}$ on aluminum was 2 to 8 hours, ${ }^{9}$ and on metals it was found to be 5 days. ${ }^{10}$ Persistence of coronaviruses on cardboard was reported to be 8 to 24 hours $^{6}$ and on wood it was found to be 4 days. ${ }^{10}$ Persistence of coronaviruses on paper has been reported to be between 24 hours ${ }^{11}$ and 4 to 5 days. ${ }^{10}$ Persistence of coronaviruses on glass was reported to be between 4 and 5 days. ${ }^{7,10}$ Persistence of coronaviruses on plastic was reported to be 72 hours ( 3 days) ${ }^{6} 8$ to 48 hours ( $<2$ days), ${ }^{8} 4$ days, ${ }^{10} 5$ days, ${ }^{12}$ and 2 to 9 days. ${ }^{13}$ Persistence of coronaviruses on silicon rubber was reported to be 3 days. ${ }^{7}$ Persistence of coronaviruses on teflon, ceramic, and PVC was found to be 5 days. ${ }^{7}$ Persistence of coronaviruses on latex 
Table 2: Persistence of human coronaviruses on various surfaces

\begin{tabular}{|c|c|c|c|}
\hline Author & Viral strain & Persistence & Reference \\
\hline \multicolumn{4}{|l|}{ Steel } \\
\hline Von Doremalen et al. ${ }^{6}$ & $\begin{array}{l}\text { SARS-CoV-2 } \\
\text { nCoV-WA1-2020 SARS-CoV-1 } \\
\text { Tor2 (AY 274,119.3) }\end{array}$ & $\begin{array}{l}72 \text { Hours for both the viruses } \\
\text { Viral titer greatly reduced after } 48 \text { hours }\end{array}$ & 6 \\
\hline Warnes et al., ${ }^{7}$ & Human coronavirus 229E & 5 Days at $21^{\circ} \mathrm{C}$ at $30-40 \% \mathrm{RH}$ & 7 \\
\hline Von Doremalen et al. ${ }^{8}$ & $\begin{array}{l}\text { MERS-CoV (isolate HCoV- } \\
\text { EMC/2012) }\end{array}$ & $\begin{array}{l}48 \text { hours at } 20^{\circ} \mathrm{C}^{\circ}-40 \% \mathrm{RH} \\
24 \text { hours }\left(30^{\circ} \mathrm{C}-30 \% \mathrm{RH}\right. \\
8 \text { hours at } 30^{\circ} \mathrm{C}-80 \% \mathrm{RH}\end{array}$ & 8 \\
\hline \multicolumn{4}{|l|}{ Copper } \\
\hline Von Doremalen et al. ${ }^{6}$ & $\begin{array}{l}\text { SARS-CoV-2 } \\
\text { nCoV-WA1-2020 SARS-CoV-1 } \\
\text { Tor2 (AY 274,119.3) }\end{array}$ & $\begin{array}{l}4 \text { Hours for SARS-Cov-2 } \\
8 \text { Hours for SARS-Cov- } 1\end{array}$ & 6 \\
\hline \multicolumn{4}{|l|}{ Aluminum } \\
\hline Sizun et al. ${ }^{9}$ & HCoV strains $229 \mathrm{E}$ and OC43 & $2-8$ Hours at $21^{\circ} \mathrm{C}$ & 9 \\
\hline \multicolumn{4}{|l|}{ Metal } \\
\hline Duan et al. ${ }^{10}$ & SARS-CoV strain P9 & 5 Days at room temperature & 10 \\
\hline \multicolumn{4}{|l|}{ Cardboard } \\
\hline Von Doremalen et al. ${ }^{6}$ & $\begin{array}{l}\text { SARS-CoV-2 } \\
\text { nCoV-WA1-2020 SARS-CoV-1 } \\
\text { Tor2 (AY 274119.3) }\end{array}$ & $\begin{array}{l}24 \text { Hours for SARS-Cov-2 } \\
8 \text { Hours for SARS-Cov- } 1\end{array}$ & 6 \\
\hline \multicolumn{4}{|l|}{ Wood } \\
\hline Duan et al. ${ }^{10}$ & SARS-CoV strain P9 & 4 Days at room temperature & 10 \\
\hline \multicolumn{4}{|l|}{ Paper } \\
\hline Lai et al. ${ }^{11}$ & SARS-CoV strain GVU6109 & 24 Hours at room temperature & 11 \\
\hline Duan et al. ${ }^{10}$ & SARS-CoV strain P9 & 4-5 Days at room temperature & 10 \\
\hline \multicolumn{4}{|l|}{ Glass } \\
\hline Warnes et al. ${ }^{7}$ & Human coronavirus $229 \mathrm{E}$ & 5 Days at $21^{\circ} \mathrm{C}$ at $30-40 \% \mathrm{RH}$ & 7 \\
\hline Duan et al. ${ }^{10}$ & SARS-CoV strain P9 & 4 Days at room temperature & 10 \\
\hline \multicolumn{4}{|l|}{ Plastic } \\
\hline Von Doremalen et al. ${ }^{6}$ & $\begin{array}{l}\text { SARS-CoV-2 } \\
\text { nCoV-WA1-2020 SARS-CoV-1 } \\
\text { Tor2 (AY 274119.3) }\end{array}$ & 72 Hours for both the viruses & 6 \\
\hline Von Doremalen et al. ${ }^{8}$ & $\begin{array}{l}\text { MERS-CoV (isolate HCoV- } \\
\text { EMC/2012) }\end{array}$ & $\begin{array}{l}48 \text { Hours at } 20^{\circ} \mathrm{C}-40 \% \mathrm{RH} \\
24 \text { Hours } 30^{\circ} \mathrm{C}-30 \% \mathrm{RH}, \\
8 \text { Hours at } 30^{\circ} \mathrm{C}-80 \% \mathrm{RH}\end{array}$ & 8 \\
\hline Chan et al. ${ }^{12}$ & $\begin{array}{l}\text { SARS-CoV } \\
\text { HKU } 39,849\end{array}$ & 5 Days at $22-25^{\circ} \mathrm{C}-40-50 \% \mathrm{RH}$ & 12 \\
\hline Rabenau et al. ${ }^{13}$ & $\begin{array}{l}\text { SARS-CoV } \\
\text { isolate FFM-1 } \\
\text { HCoV-229E }\end{array}$ & $\begin{array}{l}\text { 6-9 Days at room temperature } \\
\text { 2-6 Days at room temperature }\end{array}$ & 13 \\
\hline Duan et al. ${ }^{10}$ & SARS-CoV strain P9 & 4 Days at room temperature & 10 \\
\hline \multicolumn{4}{|l|}{ Silicone rubber } \\
\hline Warnes et al. ${ }^{7}$ & Human coronavirus $229 \mathrm{E}$ & 3 Days at $21^{\circ} \mathrm{C}$ at $30-40 \% \mathrm{RH}$ for silicone rubber & 7 \\
\hline \multicolumn{4}{|l|}{ Latex gloves } \\
\hline Sizun et al. ${ }^{9}$ & HCoV strains 229E and OC43 & $\leq 8$ Hours at $21^{\circ} \mathrm{C}$ & 9 \\
\hline \multicolumn{4}{|l|}{ Disposable gowns } \\
\hline Lai et al. ${ }^{11}$ & SARS-CoV strain GVU6109 & 2 Days at room temperature & 11 \\
\hline \multicolumn{4}{|l|}{ Teflon, ceramic, PVC } \\
\hline Warnes et al. ${ }^{7}$ & Human coronavirus $229 \mathrm{E}$ & $\begin{array}{l}5 \text { Days at } 21^{\circ} \mathrm{C} \text { at } 30-40 \% \mathrm{RH} \text { for teflon, ceramic, } \\
\text { and PVC }\end{array}$ & 7 \\
\hline
\end{tabular}

SARS, Severe Acute Respiratory Syndrome; MERS, Middle East Respiratory Syndrome; HCoV, human coronavirus; RH, relative humidity 
Table 3: Various biocidal agents and their concentrations that are effective against human coronaviruses

\begin{tabular}{|c|c|c|c|c|}
\hline Author and year & Viral strain used & Concentration & Exposure time & Reference \\
\hline \multicolumn{5}{|l|}{ Ethanol } \\
\hline Siddhartha et al. ${ }^{14}$ & MERS-CoV strain EMC & $80 \%$ & 30 Seconds & 14 \\
\hline Rabenau et al. ${ }^{13}$ & SARS-CoV Isolate FFM-1 & $\begin{array}{l}95 \% \\
85 \% \\
80 \% \\
78 \%\end{array}$ & 30 Seconds & 13 \\
\hline \multicolumn{5}{|l|}{ 2-Propanol } \\
\hline Siddhartha et al. ${ }^{14}$ & $\begin{array}{l}\text { SARS-CoV isolate FFM-1 } \\
\text { MERS-CoV strain EMC }\end{array}$ & $75 \%$ & 30 Seconds & 14 \\
\hline \multicolumn{5}{|c|}{ 2-Propanol and 1-propanol } \\
\hline Rabenau et al..$^{13}$ & SARS-CoV isolate FFM-1 & 45 and $30 \%$ & 30 Seconds & 13 \\
\hline \multicolumn{5}{|l|}{ Hydrogen Peroxide } \\
\hline Omidbakhsh et al. ${ }^{15}$ & HCoV strain 229E & $0.5 \%$ & 1 Minute & 15 \\
\hline \multicolumn{5}{|l|}{ Glutaraldehyde } \\
\hline Kariwa et al. ${ }^{16}$ & SARS-CoV Hanoi strain & $2.5 \%$ & 5 Minutes & 16 \\
\hline Rabenau et al. ${ }^{13}$ & SARS-CoV isolate FFM-1 & $0.5 \%$ & 2 Minutes & 13 \\
\hline \multicolumn{5}{|l|}{ Povidoneiodine } \\
\hline Eggers et al. ${ }^{17}$ & $\begin{array}{l}\text { SARS-CoV isolate FFM-1 } \\
\text { MERS-CoV isolate HCoV- } \\
\text { EMC/2012 }\end{array}$ & $0.23 \%$ & 15 Seconds & 17 \\
\hline Eggers et al. ${ }^{18}$ & $\begin{array}{l}\text { MERS-CoV isolate HCoV- } \\
\mathrm{EMC} / 2012\end{array}$ & $\begin{array}{l}7.5 \% \\
4 \% \\
1 \%\end{array}$ & 15 Seconds & 18 \\
\hline Kariwa et al. ${ }^{16}$ & SARS-CoV Hanoi strain & $\begin{array}{l}1 \% \\
0.25 \% \\
0.23 \%\end{array}$ & 1 minute & 16 \\
\hline
\end{tabular}

SARS, Severe Acute Respiratory Syndrome; MERS, Middle East Respiratory Syndrome; HCoV, human coronavirus

gloves was found to be $<8$ hours ${ }^{9}$ and on disposable gowns it was reported to be 2 days. ${ }^{11}$

\section{Biocidal Agents Effective Against Human Coronaviruses}

The viral load on any inanimate surface cannot be determined especially during an outbreak. So it seems logical to reduce the viral load on these surfaces by disinfection, especially surfaces that are frequently touched. WHO recommends that environmental surface cleaning and disinfection needs to be done consistently and correctly. ${ }^{24}$

Table 3 compiles the biocidal agents that are effective against coronaviruses with their concentration and time period. Even though chlorhexidine is the one of the widely used agent for disinfection in hospital setting, Chlorhexidine gluconate $(0.02 \%)$ was tested on animal coronavirus mouse hepatitis virus (MHV), and it was found to be ineffective. ${ }^{25}$

\section{Conclusion}

In the COVID era, the information obtained from different forms of media is scary and it builds unjustified apprehension. An effort was made through this review paper which presents human coronaviruses' sustainability on various surfaces under different conditions. Only a single paper presents about SARS-Cov-2 virus. Various bioactive agents are also presented out of which ethanol, 2-propanol and 1-propanol, hydrogen peroxide, glutaraldehyde, and povidone iodine was reported to be effective. There is a requirement for multiple supportive studies to unravel the mysterious SARS-CoV-2 virus. A global approach to deal with such virus would show the right avenue to combat it successfully.

\section{References}

1. Zhang JJ, Dong X, Cao YY, et al. Clinical characteristics of 140 patients infected with SARS-CoV-2 in Wuhan, China. Allergy 2020;75:1730-1741. DOI: $10.1111 /$ all.14238

2. Ghinai I, McPherson TD, Hunter JC, et al. First known person-to-person transmission of severe acute respiratory syndrome coronavirus 2 (SARS-CoV-2) in the USA. Lancet 2020;395:P1137-P1144. DOI: https:// doi.org/10.1016/S0140-6736(20)30607-3.

3. Kampf G, Todt D, Pfaender S, et al. Persistence of coronaviruses on inanimate surfaces and its inactivation with biocidal agents. J Hospital Infect 2020;104:246-251. DOI: 10.1016/j.jhin.2020.01.022

4. Ather A, Patel B, Ruparel NB, et al. Coronavirus disease 19 (COVID-19): implications for clinical dental care. J Endodont 2020;46:584-595. DOI: 10.1016/j.joen.2020.03.008

5. Ahorsu DK, Lin CY, Imani V, et al. The fear of COVID-19 scale: development and initial validation. Int J Ment Health Addict 2020;27:1-9. DOI: 10.1007/s11469-020-00270-8

6. Van Doremalen N, Bushmaker T, Morris DH, et al. Aerosol and surface stability of SARS-CoV-2 as compared with SARS-CoV-1. NEngl J Med. 2020;382(16):1564-1567. DOI: 10.13039/100006492

7. Warnes SL, Little ZR, Keevil CW. Human coronavirus $229 \mathrm{E}$ remains infectious on common touch surface materials. MBio 2015;6(6):e01697-15. DOI: https://doi.org/10.1128/mBio.01697-15

8. Van Doremalen N, Bushmaker T, Munster VJ. Stability of Middle East respiratory syndrome coronavirus (MERS-CoV) under different environmental conditions. Euro Surveill 2013;18(38):20590. DOI: 10.2807/1560-7917.es2013.18.38.20590 
9. Sizun J, Yu MW, Talbot PJ. Survival of human coronaviruses $229 \mathrm{E}$ and OC43 in suspension and after drying onsurfaces: a possible source ofhospital-acquired infections. J Hosp Infect 2000;46(1):55-60. DOI: 10.1053/jhin.2000.0795

10. Duan SM, Zhao XS, Wen RF, et al. Stability of SARS coronavirus in human specimens and environment and its sensitivity to heating and UV irradiation. Biomed Environ Sci 2003;16:246-255.

11. Lai MY, Cheng PK, Lim WW. Survival of severe acute respiratory syndrome coronavirus. Clin Infect Dis 2005;41(7):e67-e71. DOI: 10.1086/433186

12. Chan KH, Peiris JM, Lam SY, et al. The effects of temperature and relative humidity on the viability of the SARS coronavirus. Adv Virol 2011;2011. DOI: 10.1155/2011/734690

13. Rabenau HF, Cinatl J, Morgenstern B, et al. Stability and inactivation of SARS coronavirus. Med Microbiol Immunol 194(1-2):1-6.

14. Siddharta A, Pfaender S, Vielle NJ, et al. Virucidal activity ofization-recommended formulations against enveloped viruses, including zika, ebola, and emerging coronaviruses. J Infect Dis 2017;215(6):902-906. DOI: 10.1093/infdis/jix046

15. Omidbakhsh N, Sattar SA. Broad-spectrum microbicidal activity, toxicologic assessment, and materials compatibility of a new generation of accelerated hydrogen peroxide-based environmental surface disinfectant. Am J Infect Control 2006;34(5):251-257. DOI: 10.1016/j.ajic.2005.06.002.

16. Kariwa H, Fujii N, Takashima I. Inactivation of SARS coronavirus by means of povidone-iodine, physical conditions and chemical reagents. Dermatology 2006;212(Suppl. 1):119-123. DOI: 10.1159/000089211

17. Eggers $M$, Koburger-Janssen T, Eickmann $M$, et al. In vitro bactericidal and virucidal efficacy of povidone-iodine gargle/mouthwash against respiratory and oral tract pathogens. Infect Dis Ther. 2018;7(2):249-259. DOI: 10.1007/s40121-018-0200-7

18. Eggers M, Eickmann M, Zorn J. Rapid and effective virucidal activity of povidone-iodine products against Middle East respiratory syndrome coronavirus (MERS-CoV) and modified vaccinia virus Ankara (MVA). Infect Dis Ther 2015;4(4):491-501. DOI: 10.1007/s40121-015-0091-9

19. Saxena SK, ed. Coronavirus Disease 2019 (COVID-19): Epidemiology, Pathogenesis, Diagnosis, and Therapeutics. Springer Nature; 2020

20. Walls AC, Park YJ, Tortorici MA, et al. Structure, function, and antigenicity of the SARS-CoV-2 spike glycoprotein. Cell. 2020;181:281. e6-292.e6. DOI: 10.1016/j.cell.2020.02.058

21. Wrapp D, Wang N, Corbett KS, et al. Cryo-EM structure of the 2019-nCoV spike in the prefusion conformation. Science. 2020;367(6483):1260-1263. DOI: 10.13039/100000060.

22. Kumar S, Maurya VK, Prasad AK, et al. Structural, glycosylation and antigenic variation between 2019 novel coronavirus (2019-nCoV) and SARS coronavirus (SARS-CoV). Virusdisease. 2020;31:13-21.

23. Petrosillo N, Viceconte G, Ergonul O, et al. COVID-19, SARS and MERS: are they closely related? Clin Microbiol Infect 2020;26:729-734. DOI: 10.1016/j.cmi.2020.03.026

24. World Health Organization. Infection prevention and control during health care when novel coronavirus ( $\mathrm{nCoV}$ ) infection is suspected: interim guidance, 25 January 2020

25. Saknimit $M$, Inatsuki I, Sugiyama $Y$, et al. Virucidal efficacy of physico-chemical treatments against coronaviruses and parvoviruses of laboratory animals. Jikken Dobutsu 1988;37(3):341-345. DOI: 10.1538/expanim1978.37.3_341 